\title{
Reduction of Some Heavy Metals in Fibre Cement Roofing Sheet Waste-Contaminated Soil by Consortium of Bacteria and Fungi
}

\author{
Olubunmi Olufunmi Akpomie ${ }^{1}$, Catherine Ese Balogun ${ }^{1} \&$ Timothy Marhiere Akpomie ${ }^{2}$ \\ ${ }^{1}$ Delta State University Abraka, Delta State, Nigeria \\ ${ }^{2}$ Federal University of Lafia, Nasarawa State, Nigeria \\ Correspondence: Timothy Marhiere Akpomie, Department of Chemistry, Federal University of Lafia, Nasarawa \\ State, Nigeria. Tel: +234-803-3954-992 E-mail: akpomiet@yahoo.com, timothy.akpomie@science.fulafia.edu.ng
}

Received: May 14, 2020

doi:10.5539/enrr.v10n3p43
Accepted: June 26, $2020 \quad$ Online Published: September 30, 2020

URL: https://doi.org/10.5539/enrr.v10n3p43

\begin{abstract}
This research was carried out in order to ascertain the effectiveness of microbial remediation (bio-remediation) of environmental pollution by heavy metals from different sources in general and wastes from the manufacturing of fibre cement roofing sheets specifically. The concentrations of $\mathrm{Cd}, \mathrm{Cr}$, and $\mathrm{Ni}$ in fibre cement soil $(0.11,0.08$ \& $0.83)$, in dumpsite soil $(4.17,2.87 \& 40.68)$ and in surrounding soil $(2.11,1.89 \& 19.84)$ and soils outside the pollution area, control, $(1.76,0.89 \& 14.17) \mathrm{mg} / \mathrm{g}$ respectively were determined using atomic absorption spectrophotometry. Preliminary results showed that the concentration of the heavy metals; $\mathrm{Cd}, \mathrm{Cr}$, and $\mathrm{Ni}$ were all higer than values recorded by the WHO/FEPA standard. Analysis of the variance of means between the heavy metals showed differences in the respective sampled soils $(\mathrm{P}=0.209)$. The minimum inhibitory concentration (MIC) of the heavy metals on the test organisms of Bacillus sp, Rhizopus sp, proteus $s p$ and microsporium canis were obtained by the Agar diffusion method from stock culture of isolates from fibre waste dumpsites at the Department of Microbiology, Delta State University Abraka. The MIC values for Ni on the respective test organisms were; $300,150,250 \& 450, \mathrm{Cr} ; 250,400,350 \& 450$ while that for $\mathrm{Cd}$ was $900,750,900 \& 700 \mu \mathrm{g} / \mathrm{ml}$. Sterilized consortia of isolates inoculated with various combinations of bacteria and fungi were used to treat the experimental sampled soils. Concentrations of the respective heavy metals of the sampled soils were evaluated after the $1^{\text {st }}$ and $12^{\text {th }}$ week of treatments. Furthermore, the concentration of the respective heavy metals reduced in varying percentages between the $1^{\text {st }}$ and $12^{\text {th }}$ week of treatment and the results were also found to be significantly different statistically (t-calculated $>$ t-critical). Overall, the percentage reduction in the heavy metal concentrations between the $1^{\text {st }}$ and $12^{\text {th }}$ week was higher in $\mathrm{Cd}$ and $\mathrm{Cr}(76.25 \%$ \& $76.25 \%)$ respectively than in $\mathrm{Ni}(52.65 \%)$. This was an indication that microbial isolates were very effective in reducing heavy metals in fibre cement roofing sheet-wastes and from the environment.
\end{abstract}

Keywords: Roofing sheets, Bioremediation, Heavy metals, Microbial Isolates, Environment, fibre cement

\section{Introduction}

The anthropogenic activities of man which include the springing up of several industries such as leather, rubber, asbestos, roofing sheets, pharmaceuticals have resulted in an increase of discharge of heavy metals to water bodies and land thus causing undesirable effects which negatively impact on the physicochemical and biological properties of soils and water (Ipeaiyeda et al., 2012, Yuyao et al., 2018).

Fibre cement roofing sheet found to be durable, cool, produce less heat, does not easily rust, heat resistant and light (Zheng \& Antonio, 2005) is now in vogue. The wastes from roofing sheet industry are termed inert or nuisance dust and are categorized as "Red" because of the presence of heavy metals such as $\mathrm{Ni}, \mathrm{Pb}, \mathrm{Co}, \mathrm{Cr}$ which are hazardous to man, animals and plant (Zeyede et al., 2010). Metals are highly toxic, persistent and not biodegradable so impairs the natural ecosystem and consequently affect human health via the food chain. (Tang et al. 2018).

Fibre cement is composed of hydraulic binder, heavy metals, additives, reinforcing fibre which includes cellulose fibre, polyvinylacrylamide, polyvinylchloride, lignin, viscosity enhancing agent (hydroxyethyl methycellulose) and filler $\left(\mathrm{CaCO}_{3}\right.$, Chromium, Iron Oxide, Propylene fibre) (Zeyede et al., 2010). These components constitute environment hazards to soil, water and air when discharged indiscriminately. The action of water, sun, ice, wind, 
moss, lichens and pollutants such as acid rain, $\mathrm{SO}_{2}$ may cause corrosion which gradually releases the asbestos fibres and heavy metals in the matrix (Beddoe \&Dorner, 2005).

An increase in the toxicity of heavy metals in the environment may eventually reach man and animals through the food chain thereby necessitating its removal from the polluted natural environment (Irma et al., 2013). The impact of the heavy metals in the soil manifests in several ways such as affecting soil respiration (Blagodatskaya et al., 2006), lead to physiological dysfunction and malnutrition in plants and plant seed, can accumulate in the human body causing, in some cases irreversible harm to human health (Singh et al., 2015).

The conventional methods of remediating heavy metals from contaminated sites are excavation, solidification and stabilization and other methods such as adsorption of the chemical materials (Choski \&Jozi, 2007; Al - Muhtaseb et al., 2008). These temporarily remove heavy metals and have the disadvantages of being expensive, generation of secondary metabolites which are hazardous and inefficiency (Bahn et al., 2012). Biological techniques on the other hand, address these setbacks since they are easy to operate, cost-effective and do not produce secondary pollutants hence are eco-friendly. They also help in retaining the soil structure and the pollutants and microbes can almost completely be removed from the polluted environment (Yuyao et al., 2018).

The use of microbial remediation is becoming common and is considered promising due to its many advantages (Singh \&Prasad, 2015). In bioremediation processes, microorganisms use the contaminants as nutrients or sources of energy (Kumar et al., 2011; Asha et al., 2013). The microbial populations respond to heavy metal contamination based on the concentration and bioavailability of the metals. These are affected by factors such as environmental conditions (Zhang et al., 2019; Du et al., 2018). The microbial survival in heavy metal polluted soils depends on biochemical properties, physiological and/or genetic adaptation which includes morphological, environmental modification of metal speciation (Shanab et al., 2007). Heavy metal reduction by microorganism can occur passively (biosorption) or actively (bioaccumulation). Irma et al. (2013) found that Aspergillus fumigatus has good biosorption capacity towards some heavy metals. Vargas et al. (2009) discovered that fungi isolated from compost were able to detoxify metal polluted environments.

In Nigeria, the usage of fibre cement roofing sheet is still in practice and there is not much research on the natural remediation of the environment in which the wastes are disposed so as to ensure a safe environment. This research aims at using indigenous microorganisms present in Eternit fibre cement roofing sheet waste in removing or reducing some heavy metals present in the waste which may constitute hazards to man and the environment. Numerous microbial species such as Bacillus, Pseudomonas, Streptomyces, Aspergillus, Rhizopus and Penicillium have significant heavy metal removal ability. (Wierzeba, 2015; Dasola, 2014).

\section{Materials and Methods}

\subsection{Collection of Samples}

\subsubsection{Experimental Organisms}

Proteus sp, Bacillus sp., were collected on prepared sterile Nutrient Agar plates and Aspergillus niger and Microsporium canis on Potato Dextrose Agar plates from Microbiology Laboratory, Delta State University, Abraka from stock culture of organisms isolated from roofing sheet waste.

\subsection{Fibre Cement Waste and Soil Samples}

The samples were collected in polythene bags using auger at different points within the dumpsite at a depth of 0 $30 \mathrm{~cm}$. Samples were collected from the factory waste soil within the factory, dumpsite and a control from a point where there was roofing sheet production activity. The samples were transported to the Microbiology laboratory, Delta State University, Abraka in icepacks for analyses.

\subsection{Microbiological Analysis}

\subsubsection{Ability of Isolates to Grow on Fiber Cement Waste}

Mineral Salt Agar (MSA) incorporated with fibre cement waste (FCW) were used to test the ability of isolates to utilize fibre cement waste. The modified method of Akpomie et al., (2016) was used in preparing fibre cement waste agar. Here, fibre cement waste $(100 \mathrm{~g})$ was autoclaved at $121^{\circ} \mathrm{C}$ for $30 \mathrm{mins}$ before filtering through glass wool. The filtrate was made up to the litre mark with freshly distilled water incorporated with mineral salts $(\mathrm{g} / \mathrm{l}$;

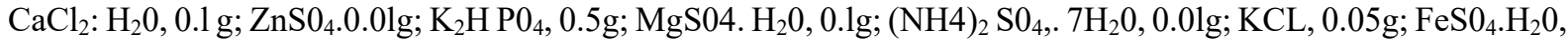
$0.1 \mathrm{~g}$ thereafter $15 \mathrm{~g}$ of agar powder was added for solidification. This was autoclaved for $30 \mathrm{mins}$, allowed to cool and poured into plates. The plates were inoculated with the bacteria and fungi and incubated at $28 \pm 2^{\circ} \mathrm{c}$ for $24 \mathrm{~h}$ and $72 \mathrm{~h}$ respectively. 


\subsection{Treatment of Waste}

The ball-milled fibre cement, dumpsite and soil samples were autoclaved at $120^{\circ} \mathrm{C}$ for 30 mins and treated with standardized inoculum of the isolates (singly and in combinations). The controlled samples were not treated with microorganisms.

\subsection{Inoculum Development and Standardization}

\subsubsection{Bacterium:}

Each bacterium inoculum was prepared by suspending $18 \mathrm{~h}$ bacterium isolates in sterile normal saline $(0.89 \% \mathrm{NaCl})$. The turbidity of the bacterial suspension was then adjusted to $0.5 \mathrm{McF}$ arland Standard which is equivalent to 1.5 $\mathrm{x} 10^{8}(\mathrm{fu} / \mathrm{ml})$.

\subsubsection{Fungi:}

The fungal inoculums were prepared by flooding the surface of Potato Dextrose. Agar slants inoculated with each fungus with sterile distilled water. The spores of the aerial mycelia were scraped with a loop and weighed

\subsection{Determination of Minimum Inhibitory Concentration of the heavy metals on the isolates.}

The MIC of the metals were determined by the Agar diffusion methods (Hassan et al; 2008) as described by (Vehisamy et al., 2011). Stock solution of the metals $(1000 \mu \mathrm{g} / \mathrm{ml})$ were prepared by weighing $\mathrm{K}_{2} \mathrm{Cr}_{2} \mathrm{O}_{7}$, $\mathrm{Cd}\left(\mathrm{CH}_{3} \mathrm{CO}_{2}\right)$ and $\mathrm{NiCl}_{2}$ and dissolved in $1000 \mathrm{ml}$ of sterile distilled water. The solution was mixed thoroughly and strengths of different concentrations (Cr: 400, 350, 300, 250 and $200 \mu \mathrm{g} / \mathrm{ml} ; \mathrm{Cd}: 1000,950,900,850$ and 800 $\mu \mathrm{g} / \mathrm{ml}$ and $\mathrm{Ni}: 400,350,300,250,200$ and $150 \mu \mathrm{g} / \mathrm{ml}$ ) were made by double dilution method.

The microorganisms were subjected to growth in the different concentrations and observations were made after $24 \mathrm{~h}$ and $72 \mathrm{~h}$ incubation for bacteria and fungi respectively.

\subsection{Treatment with Single Isolates}

The fibre cement waste samples were wrapped in aluminium foil and sterilized in an autoclave at $121^{\circ} \mathrm{C}$ for $20 \mathrm{mins}$ before inoculation.

Bacteria: Ten millimetre $(10 \mathrm{ml})$ mineral salt solution of each bacterium was introduced into polythene bags containing $200 \mathrm{~g}$ of each sample (in triplicates). They were kept at $28 \pm 2^{\circ} \mathrm{C}$ for twelve weeks, after which the concentrations of the metals were determined. Samples were mixed intermittently and $100 \mathrm{ml}$ of sterile distilled water was added every $48 \mathrm{hr}$.

\subsection{Treatment with Consortia of Isolates}

Sterilized samples were inoculated with various combinations of bacteria and fungi.

\subsubsection{Combination of Bacillus and Proteus sp}

A $5 \mathrm{ml}$ mineral salt suspension of each bacterium was mixed together and poured into $200 \mathrm{~g}$ of sterilized samples and incubated at $28 \pm 2^{\circ} \mathrm{C}$ for 12 weeks. They were mixed intermittently with $100 \mathrm{ml}$ of distilled water every $48 \mathrm{hrs}$.

\subsubsection{Consortium of fungi}

Ten gram of each fungus was weighed and mixed together, thereafter was added to $200 \mathrm{~g}$ of sterilized samples.

\subsubsection{Consortium of all bacteria and fungi}

This was done by mixing $2.5 \mathrm{~g}$ of each fungus and $50 \mathrm{ml}$ mineral salt suspension of each bacterium. They were mixed and introduced into $200 \mathrm{~g}$ of sterilized samples. Samples with no inoculum served as control for all the treatments.

\subsection{Heavy Metal Analysis}

$\mathrm{Cr}, \mathrm{Cd}$ and Ni were analyzed using Atomic Absorption Spectrophotometry (APHA, 2004). The acid extraction was done using the method 3050B (USEPA, 1996). One gram of sample was placed in 250ml flask for digestion. The sample was heated to $95^{\circ} \mathrm{C}$ in $10 \mathrm{ml}$ of $50 \% \mathrm{HNO}_{3}$. It was allowed to cool then refluxed with repeated additions of $60 \% \mathrm{HNO}_{3}$ until no brown fumes were given off by the sample. The solution was allowed to evaporate until the volume was reduced to $5 \mathrm{ml}$. After cooling, $10 \mathrm{ml}$ of $30 \% \mathrm{H}_{2} \mathrm{O}_{2}$ was added slowly without allowing any loss. The mixture was again refluxed with $10 \mathrm{ml}$ of $37 \% \mathrm{HCl}$ for 15 minutes. The digestate obtained was filtered through $0.45 \mu \mathrm{m}$ membrane filter, diluted to $150 \mathrm{ml}$ with deionized water and stored at $4{ }^{\circ} \mathrm{C}$ for analyses.

The concentrations of the heavy metal were measured using atomic absorption spectroscopy (AAS machine: Agilent Technology and 55AA Atomic Absorption Spectrophotometer). The respective reduction in the metal concentrations were calculated using the expression; 
$\frac{\text { Initial con centration of metal - final concentration }}{\text { Initial concentration }} \times 100$

The one way anova statistical method was used to analyze the result (appendix E).

\section{Results \& Discussion}

Table 1. Concentration of Cadmium, Chromium and Nickel in the Samples (mg/g)

\begin{tabular}{llllll}
\hline Heavy metals & Fibre & Dumpsite & Soil & Control & WHO/FEPA Standard \\
\hline Cadmium $(\mathrm{Cd})$ & 0.11 & $* 4.17$ & $* 2.11$ & 1.76 & 0.30 \\
Chromium $(\mathrm{Cr})$ & 0.08 & $* 2.87$ & 1.89 & 0.89 & 2.00 \\
Nickel $(\mathrm{Ni})$ & 0.83 & $* 40.68$ & $* 19.84$ & 14.17 & 0.02 \\
\hline
\end{tabular}

* high concentration compared to WHO/FEPA Standards

Table 1 gives the varying concentrations of the heavy metals $(\mathrm{Cd}, \mathrm{Cr}$ and $\mathrm{Ni})$ in the respective fibre and soil samples. Concentrations were all high and differed among the samples. These concentrations were also noted to be higher than the WHO/FEPA standard except in the fibre samples (see appendix D). The heavy metals may have been introduced into the samples at various points of processing. The high concentration at the dumpsite may have resulted from accumulation over time and that of the surrounding soil could be from leachate.

Table 2. Minimum Inhibitory Concentrations (MIC) of the Heavy Metals on Test Organisms $(\mu \mathrm{g} / \mathrm{ml})$

\begin{tabular}{llll}
\hline Isolates & Nickel & Chromium & Cadmium \\
\hline Bacillus $\mathrm{sp}$ & 300 & 250 & 900 \\
Rhizopus $s p$ & 150 & 400 & 750 \\
Proteus $s p$ & 250 & 350 & 1000 \\
Microsporium canis & 450 & 450 & 700 \\
\hline
\end{tabular}

In Table 2, Ni and $\mathrm{Cr}$ showed a more pronounced inhibitory effect on the organisms than $\mathrm{Cd}$. This may be that $\mathrm{Ni}$ and $\mathrm{Cr}$ possessed a higher antimicrobial activity than $\mathrm{Cd}$. All three heavy metals may have inhibited the microorganisms by interacting with the enzymes directly involved or those involved in general metabolism. Cadmium is known to significantly influence the enzymes of microorganism except when they develop resistance to the metal (Chingching et al., 2008). The organisms exhibited a high resistance to the metals. Many bacteria make metals less toxic thus making organisms that live in heavy metal contaminated site potentially useful in bioremediation. The ability of the organisms to reduce the heavy metals and grow in their presence may be attributed to the fact that microorganisms develop ingenuous mechanisms of metal resistance and detoxification which may include electrostatic interaction, ion exchange, precipitation, redox process and surface complexation, metal oxidation, metal effluxes. The degree of utilization of the metals varied among the organisms.

Table 3a. Effect of Treatment on the Cadmium Concentration in Soil, Fibre-cement and Waste Dumpsite after 12 Weeks

\begin{tabular}{|c|c|c|c|c|}
\hline \multirow[t]{2}{*}{ Treatment } & \multicolumn{3}{|c|}{ Cadmium Concentration } & \multirow{2}{*}{$\begin{array}{l}\text { Reduction After } 12 \\
\text { Weeks (\%) }\end{array}$} \\
\hline & $\mathbf{0 ~ h}$ & $1^{\text {st }}$ Week & $12^{\text {th }}$ Week & \\
\hline Fibre waste without inoculum & 0.11 & 0.104 & 0.100 & 9.09 \\
\hline Fibre + all organisms & 0.11 & 0.047 & 0.026 & 76.36 \\
\hline Fibre + all bacteria & 0.11 & 0.068 & 0.046 & 58.18 \\
\hline Fibre + all fungi & 0.11 & 0.081 & 0.052 & 52.72 \\
\hline Fibre+Bacillus sp & 0.11 & 0.094 & 0.073 & 33.64 \\
\hline Fibre + Proteus sp & 0.11 & 0.090 & 0.070 & 36.36 \\
\hline Fibre + Microsporium sp & 0.11 & 0.100 & 0.083 & 24.50 \\
\hline Dumpsite (control) & 4.17 & 0.097 & 0.080 & 27.27 \\
\hline Dumpsite + all organisms & 4.17 & 4.168 & 4.161 & 0.24 \\
\hline Dumpsite + all bacteria & 4.17 & 2.103 & 1.580 & 62.11 \\
\hline Dumpsite + all fungi & 4.17 & 3.224 & 2.849 & 30.70 \\
\hline Dumpsite + Bacillus sp & 4.17 & 3.368 & 3.315 & 20.50 \\
\hline Dumpsite + proteus $s p$ & 4.17 & 3.979 & 3.001 & 28.03 \\
\hline Dumpsite + Microsporium sp & 4.17 & 4.025 & 3.750 & 10.07 \\
\hline Dumpsite + Rhizopus sp & 4.17 & 4.096 & 4.007 & 3.91 \\
\hline Soil (control) & 2.11 & 4.084 & 3.990 & 4.32 \\
\hline Soil + all organisms & 2.11 & 2.109 & 2.105 & 0.20 \\
\hline
\end{tabular}




\begin{tabular}{lllll} 
Soil + all bacteria & 2.11 & 1.442 & 1.140 & 45.97 \\
Soil + all fungi & 2.11 & 1.718 & 1.544 & 26.82 \\
Soil + Bacillus sp & 2.11 & 1.733 & 1.590 & 24.64 \\
Soil + proteus $\boldsymbol{s p}$ & 2.11 & 1.838 & 1.782 & 15.55 \\
Soil + Rhizopus $\boldsymbol{s p}$ & 2.11 & 2.004 & 1.872 & 11.28 \\
Soil + Microsporium $\boldsymbol{s p}$ & 2.11 & 2.103 & 1.850 & 12.32 \\
\hline
\end{tabular}

The above table gives the concentrations of $\mathrm{Cd}$ in the various samples before treatment $(0 \mathrm{~h})$ and after the $1^{\text {st }}$ and $12^{\text {th }}$ week of microbial treatments. Generally, the result showed that in all samples, there were varied reductions in the heavy metal concentration between the $1^{\text {st }}$ and $12^{\text {th }}$ week of microbial treatments. The highest $\%$ reduction in $\mathrm{Cd}(76.36 \%)$ was observed in the fiber sample inoculated with all microbial isolates. This was against the 62.11 and $45.97 \%$ observed in dumpsite and soil control samples respectively. Statistical treatment of the data suggests that there was significant difference between the $1^{\text {st }}$ and $12^{\text {th }}$ week of treatment of the waste with the microbial isolates, see appendix A. This maybe indicative of of the reliability of the method.

Table 4. Effect of Treatment on Chromium Concentration in Soil, Fibre-cement and Waste Dumpsite after $1^{\text {st }}$ and $12^{\text {th }}$ Weeks

\begin{tabular}{|c|c|c|c|c|}
\hline \multirow[t]{2}{*}{ Treatment } & \multirow[b]{2}{*}{$\mathbf{0 ~ h}$} & \multicolumn{2}{|c|}{ Chromium Concentration } & \multirow{2}{*}{$\begin{array}{c}\text { Reduction } \\
\text { after } 12 \text { weeks }(\%)\end{array}$} \\
\hline & & $1^{\text {st }}$ week & $12^{\text {th }}$ week & \\
\hline Fibre (control) & 0.08 & 0.077 & 0.073 & 8.75 \\
\hline Fibre + all organisms & 0.08 & 0.062 & 0.019 & 76.25 \\
\hline Fibre + all bacteria & 0.08 & 0.065 & 0.036 & 55.00 \\
\hline Fibre + all fungi & 0.08 & 0.067 & 0.043 & 46.25 \\
\hline Fibre + Bacillus sp & 0.08 & 0.071 & 0.048 & 40.00 \\
\hline Fibre + proteus $s p$ & 0.08 & 0.070 & 0.044 & 45.00 \\
\hline Fibre + Rhizopus sp & 0.08 & 0.073 & 0.057 & 28.75 \\
\hline Fibre ++ Microsporium $s p$ & 0.08 & 0.072 & 0.052 & 35.00 \\
\hline Dumpsite (control) & 2.87 & 2.862 & 2.840 & 1.05 \\
\hline Dumpsite + all organisms & 2.87 & 1.654 & 1.105 & 61.50 \\
\hline Dumpsite + all bacteria & 2.87 & 1.738 & 1.314 & 54.22 \\
\hline Dumpsite + all fungi & 2.87 & 1.748 & 1.418 & 50.59 \\
\hline Dumpsite + Bacillus sp & 2.87 & 1.997 & 1.463 & 49.02 \\
\hline Dumpsite + proteus $s p$ & 2.87 & 2.532 & 2.118 & 26.20 \\
\hline Dumpsite + Rhizopus sp & 2.87 & 2.724 & 2.440 & 14.98 \\
\hline Dumpsite + Microsporium $s p$ & 2.87 & 2.750 & 2.539 & 38.05 \\
\hline Soil (control) & 1.89 & 1.888 & 1.820 & 3.70 \\
\hline Soil + all organisms & 1.89 & 0.886 & 0.422 & 77.67 \\
\hline Soil + all bacteria & 1.89 & 0.995 & 0.755 & 60.05 \\
\hline Soil + all fungi & 1.89 & 1.097 & 0.823 & 56.46 \\
\hline Soil + Bacillus $s p$ & 1.89 & 1.397 & 1.049 & 44.50 \\
\hline Soil + proteus sp & 1.89 & 1.581 & 1.290 & 31.75 \\
\hline Soil + Rhizopus sp & 1.89 & 1.745 & 1.479 & 21.75 \\
\hline Soil + + Microsporium sp & 1.89 & 1.651 & 1.365 & 27.77 \\
\hline
\end{tabular}

Table $4 \mathrm{a}$ is the result obtained upon the determination of the \% reduction in the concentration of $\mathrm{Cr}$ in the various samples after treatment with the microbial isolates and after the $1^{\text {st }}$ and $12^{\text {th }}$ week. The obtained results showed a similar trend with those of $\mathrm{Cd}$. Between the range of measurement, there were also varying degrees in percentage reduction of the heavy metals when treated with all forms of the various microbial isolates. Though treatment of the fibre and any of the individual microbial isolate was effective in reducing the heavy metal concentration, the treatment with all organisms, $76.25 \%$, was highest when compared to 61.50 and $77.67 \%$ for the Dumpsite with all organisms and soil with all organisms respectively. Additionally, statistical treatment, appendix B showed that there was significant difference between the $1^{\text {st }}$ and $12^{\text {th }}$ week of treatments. 
Table 5. Effect of Treatment on Nickel Concentration of Soil, Fibre-cement and Waste Dumpsite after the $1^{\text {st }}$ and $12^{\text {th }}$ Weeks

\begin{tabular}{|c|c|c|c|c|}
\hline \multirow{2}{*}{ Treatment } & \multicolumn{3}{|c|}{ Nickel Concentration } & \multirow{2}{*}{$\begin{array}{l}\text { Reduction } \\
\text { after 12weeks (\%) }\end{array}$} \\
\hline & $\mathbf{O} \mathbf{h}$ & $1^{\text {st }}$ week & $12^{\text {th }}$ week & \\
\hline Fibre (control) & 0.83 & 0.827 & 0.823 & 0.84 \\
\hline Fibre + all organisms & 0.83 & 0.462 & 0.398 & 52.65 \\
\hline Fibre + all bacteria & 0.83 & 0.541 & 0.519 & 37.47 \\
\hline Fibre + all fungi & 0.83 & 0.697 & 0.652 & 21.45 \\
\hline Fibre + Bacillus $s p$ & 0.83 & 0.751 & 0.698 & 15.90 \\
\hline Fibre + proteus sp & 0.83 & 0.720 & 0.706 & 14.94 \\
\hline Fibre + Rhizopus $s p$ & 0.83 & 0.810 & 0.766 & 7.71 \\
\hline Fibre ++ Microsporium sp & 0.83 & 0.807 & 0.785 & 5.42 \\
\hline Dumpsite (control) & 40.68 & 40.670 & 40.598 & 0.20 \\
\hline Dumpsite + all organisms & 40.68 & 37.235 & 32.598 & 19.87 \\
\hline Dumpsite + all bacteria & 40.68 & 38.524 & 34.926 & 14.14 \\
\hline Dumpsite + all fungi & 40.68 & 38.963 & 35.986 & 11.54 \\
\hline Dumpsite + Bacillus sp & 40.68 & 39.752 & 36.526 & 10.21 \\
\hline Dumpsite + proteus $s p$ & 40.68 & 46.600 & 38.265 & 5.05 \\
\hline Dumpsite + Rhizopus sp & 40.68 & 40.519 & 38.212 & 6.07 \\
\hline Dumpsite+ Microsporium sp & 40.68 & 40.680 & 38.230 & 6.02 \\
\hline Soil (control) & 19.84 & 18.474 & 19.800 & 0.20 \\
\hline Soil + all organisms & 19.84 & 19.003 & 12.532 & 36.83 \\
\hline Soil + all bacteria & 19.84 & 19.056 & 13.210 & 33.42 \\
\hline Soil + all fungi & 19.84 & 19.512 & 14.264 & 28.10 \\
\hline Soil + Bacillus sp & 19.84 & 19.684 & 15.160 & 23.59 \\
\hline Soil + proteus $s p$ & 19.84 & 19.752 & 15.642 & 21.14 \\
\hline Soil + Rhizopus sp & 19.84 & 19.009 & 16.321 & 17.73 \\
\hline Soil + Microsporium sp & 19.84 & 19.752 & 16.116 & 18.77 \\
\hline
\end{tabular}

Table 5a is the result for the analysis of Nickel. The trend is similar to those of Cadmium and Chromium. However, the percentage reduction in the concentration of $\mathrm{Ni}$ was much lower than that of $\mathrm{Cd}$ and $\mathrm{Cr}$. For $\mathrm{Ni}$, the three categories were $52.65,19.87$ and $36.38 \%$ respectively. There was also a significant difference between the $1^{\text {st }}$ and $12^{\text {th }}$ week of fiber sample treatment of this heavy metal with all the microbial isolates. See appendix C.

Table 6. pH of Contaminated Soil, Fibre-cement and Fibre-waste Dumpsite Before and After the Different Treatments

\begin{tabular}{|c|c|c|c|c|c|c|}
\hline \multirow{2}{*}{ Treatment } & \multicolumn{2}{|c|}{ fibre-cement } & \multicolumn{2}{|c|}{ Dumpsite } & \multicolumn{2}{|c|}{ Soil } \\
\hline & $\mathbf{a}$ & $\mathbf{b}$ & $\mathbf{a}$ & b & $\mathbf{a}$ & $\mathbf{b}$ \\
\hline Control & 8.2 & 8.0 & 7.8 & 8.2 & 8.0 & 8.5 \\
\hline All organisms & 8.2 & 8.0 & 7.8 & 8.0 & 8.0 & 7.8 \\
\hline Proteus sp + Bacillus sp & 8.2 & 8.3 & 7.8 & 8.2 & 8.0 & 7.2 \\
\hline Rhizopus +Microsporium & 8.2 & 8.7 & 7.8 & 8.2 & 8.0 & 8.5 \\
\hline Bacillus sp & 8.2 & 8.5 & 7.8 & 8.2 & 8.0 & 8.0 \\
\hline Rhizopus sp & 8.2 & 8.7 & 7.8 & 7.9 & 8.0 & 7.8 \\
\hline Microsporium sp & 8.2 & 8.3 & 7.8 & 7.9 & 8.0 & 8.0 \\
\hline Proteus sp. & 8.2 & 8.2 & 7.8 & 7.6 & 8.0 & 9.0 \\
\hline
\end{tabular}

$\mathrm{a}=$ before treatment; $\mathrm{b}=$ after treatment.

Table 6 gives the $\mathrm{pH}$ of the various samples before and after treatments with the microbial isolates. All $\mathrm{pH}$ values were shown to be basic in nature. The difference in activities of the organism may be attributed to the fact that $\mathrm{pH}$ affects the activity of enzyme in microorganisms thus affecting the rate of microbial metabolism of heavy metals thus may contribute to microorganisms reacting differently to different $\mathrm{pH}$ values. $\mathrm{pH}$, temperature, substrate species, substrate concentration all, affect heavy metal removal by microorganisms (Marchenko et al., 2015; Gola et al., 2016; Park et al., 2016). These may have contributed to the varying degrees of the ability of the microorganisms to remediate the heavy metals in the soil. This may also be due to the bioavailability of the heavy metals and the adsorbed dose (Rasmussen et al., 2000).

Furthermore, heavy metals may break vital enzymatic functions, disrupt ion regulation and/or directly affect the formation of DNA as well as protein (Gauthier at al., 2014; Hildebrandt et al., 2007) which may have contributed to the poor reduction of some of the metals (especially Nickel) by Proteus sp and Aspergillus sp. The microbial 
cells in this study may have been able to reduce the level of the heavy metals especially chromium and Cadmium through bioaccumulation, biosorption and/or through other mechanisms.

Fungal species isolated from industrial wastes have been found to exhibit resistance to heavy metals which are found naturally and become concentrated as a result of human activities (Vidali, 2001). The reduction may further be explained by adsorption which normally does not depend on energy metabolism and occurs exclusively in living cells (Wang, 2001). Microbes adsorb a high amount of heavy metal ions rapidly. Bacillus was found to adsorb $\mathrm{Cu}^{2+}$ (Tebo, 1998). It may also be by complexation or reflux reactions thus changing the valence of the metal which can affect their mobility or toxicity (Gavrilescu, 2007). Kotas and Stkiska (2000) showed that many genera of microbes including bacteria, some yeasts and fungi help in bioremediation of chromium and metal contaminated soils and waste by bio-absorption and bioaccumulation. The organisms that utilized the heavy metals varied, depending on the chemical nature of the agents because microorganisms cannot destroy metals but can influence their mobility in the environment by modifying their physical and chemical characteristics.

Practically, all the treatments with the organisms reduced the metal levels introduced from the fibre cement activity. The report of Irma et al. (2013) showed that the ability of some microorganisms to tolerate heavy metals and to promote transformations may be through adsorption. Several microorganisms like bacteria, fungi and algae have been used to clean up heavy metal contaminated environment (Neha et al., 2013; Srivasta et al. 2015). Park et al. (2005) isolated Rhizopus sp which was able to bioremediate chromium metals. Li et al., (2015) also reported a Rhizopus sp which can easily remove $\mathrm{ZN}, \mathrm{Cu}, \mathrm{Cd}$ and $\mathrm{Th}$.

However, the fungi (Aspergillus niger and Microsporium canis) in this study were not efficient in the heavy metal removal. This may be due to the strain of fungal species used and also the environment from which it was isolated. The treatments with consortia of organisms reduced the metals more than other treatments which may be attributed to microorganisms living in mixed colonies comprising of different species and genera of organisms where there is synergy of different metabolic activities. Many researchers have reported the higher effectiveness of consortia of microorganisms for bioremediation of heavy metals than single organisms (Kader et al., 2007); Mosa et al., 2016; Abioye et al., 2018) which conforms with the findings of this study where the different combinations of the consortia gave a better result than single treatment procedures.

\section{Conclusion}

All the organisms were able to grow on the fibre cement medium showing their ability to tolerate high metal concentrations induced by the fibre cement. The Minimum Inhibitory Concentrations of the metals on the microorganisms further confirmed the potential of the organisms to grow at high metal concentrations especially Cadmium and Chromium. Hence, the organisms were quite effective in reducing the levels of the metals at varying degrees. The treatment of the fibre, dumpsite and polluted soil with the consortia of all organisms and all bacteria was more effective than all fungi and treatment with individual organisms. The all bacteria and all organisms protocol of treatment significantly reduced the levels of the chromium and Cadmium and to an extent the nickel present in the heavy metal polluted fibre cement samples. The consortium of Bacillus $\mathrm{sp}$, Proteus sp, Rhizopus sp and Microsporium sp can be used in the treatment of waste from fibre cement roofing sheet industry and in bioremediating polluted soils from such activities.

Further work is suggested on expanding the focus on genetics of the organisms and other organisms and the specific mechanism of action of the organisms so as to enhance the metal reduction potential in fibre cement which is an area that has not been well researched into.

\section{Acknowledgements}

This research was self-funded. However, the authors are grateful to the managements and staff of the Departments of Microbiology and Chemistry, Delta State University Abraka, Nigeria, for the use of their laboratory equipments and reagents for the various analyses carried out in the course of this research.

\section{Conflict of Interest}

The authors declare that there is no conflict of interests regarding the publication of this paper.

\section{References}

Abioye, O. P., Oyewole, O. A., Oyeleke, S. B., Adeyemi, M. O., \& Orukotan, A. A. (2018). Biosorption of lead, chromium and cadmium in tannery effluent using indigenous microorganisms. Brazilian Journal of Biological Sciences, 5(9), 25-32. https://doi.org/10.21472/bjbs.050903 
Akob, D. M., Mills, H. J., \& Kostka, J. E. (2007). Metabolically active microbial communities in uraniumcontaminated subsurface sediments. FEMS Microbiology Ecology, 59(1), 95-107. https://doi.org/10.1111/j.1574-6941.2006.00203.x

Akpomie, O. O., \& Ejechi, B. O. (2016). Removal of Cr (VI) from tannery effluents with mixed cultures of bacteria and fungi isolated from soils contaminated with tropical tannery effluents. International Journal of Environment and Waste Management, 17(1), 60-70. https://doi.org/10.1504/IJEWM.2016.076431

Al-Muhtaseb, S. A., El-Naas, M. H., \& Abdallah, S. (2008). Removal of aluminum from aqueous solutions by adsorption on date-pit and BDH activated carbons. Journal of Hazardous Materials, 158(2-3), 300-307. https://doi.org/10.1016/j.jhazmat.2008.01.080

APHA (American Public Health Association). (2004). Standard methods for the Examination of waste and waste water ed Washington, DC. 56P.

Asha, C. P., \& Sandeep, R. S. (2013). Review on Bioremediation- Potential tool for removing environmental pollution. International Journal of Basic and Applied Chemical Science 1, 2277.

Liu, Y. G., Zhou, M., Zeng, G. M., Wang, X., Li, X., Fan, T., \& Xu, W. H. (2008). Bioleaching of heavy metals from mine tailings by indigenous sulfur-oxidizing bacteria: Effects of substrate concentration. Bioresource Technology, 99(10), 4124-4129. https://doi.org/10.1016/j.biortech.2007.08.064

Barral, S., Guerreiro, A., Villa-García, M. A., Rendueles, M., Díaz, M., \& Piletsky, S. (2010). Synthesis of 2(diethylamino)ethyl methacrylate-based polymers. Reactive and Functional Polymers, 70(11), 890-899. https://doi.org/10.1016/j.reactfunctpolym.2010.08.003

Blagodatskaya, E. V., Pampura, T. V., Myakshina, T. N., \& Dem'yanova, E. G. (2006). The influence of lead on the respiration and biomass of microorganisms in gray forest soil in a long-term field experiment. Eurasian Soil Science, 39(5), 498-506. https://doi.org/10.1134/S1064229306050061

Campopiano, A., Ramires, D., Zakrzewska, A. M., Ferri, R., D’Annibale, A., \& Pizzutelli, G. (2009). Risk assessment of the decay of asbestos cement roofs. Annals of Occupational Hygiene, 53(6), 627-638. https://doi.org/10.1093/annhyg/mep036

Chien, C., Kuo, Y., Chen, C., Hung, C., Yeh, C., \& Yeh, W. (2008). Microbial diversity of soil bacteria in agricultural field contaminated with heavy metals. Journal of Environmental Sciences, 20(3), 359-363. https://doi.org/10.1016/S1001-0742(08)60056-X

Choksi, P. M., \& Joshi, V. Y. (2007). Adsorption kinetic study for the removal of nickel (II) and aluminum (III) from an aqueous solution by natural adsorbents. Desalination, 208(1-3), 216-231. https://doi.org/10.1016/j.desal.2006.04.081

Cipurkovic, A., Trumic, I., Hodžic, Z., Selimbašic, V., \& Djozic, A. (2014). Distribution of heavy metals in Portland cement production process. Advances in Applied Science Research, 5(6), 252-259.

Dasola, M., Adeyemi, L., \& Tunbosun, A. (2014). Kinetic and equilibrium studies of the heavy metal remediation potential of Helix pomentia. 8(9), 123-133. https://doi.org/10.5897/AJPAC2014.

Du, P. X., Zhang, Y., Wei, W. Y., \& Tang, Q. (2018). Strength and environmental characteristics of cement solified heavy metal contaminated soil. Science, Engineering and Technology, 18(21), 146-154.

Gauthier, P. T., Norwood, W. P., Prepas, E. E., \& Pyle, G. G. (2014). Metal-PAH mixtures in the aquatic environment: A review of co-toxic mechanisms leading to more-than-additive outcomes. Aquatic Toxicology, 154, 253-269. https://doi.org/10.1016/j.aquatox.2014.05.026

Gavrilescu, M. (2004). Removal of heavy metals from the environment by biosorption. Engineering in Life Sciences, 4(3), 219-232. https://doi.org/10.1002/elsc.200420026

Gola, D., Dey, P., Bhattacharya, A., Mishra, A., Malik, A., Namburath, M., \& Ahammad, S. Z. (2016). Multiple heavy metal removal using an entomopathogenic fungi Beauveria bassiana. Bioresource Technology, 218, 388-396. https://doi.org/10.1016/j.biortech.2016.06.096

Gupta, A., \& Joia, J. (2016). Microbes as Potential Tool for Remediation of Heavy Metals: A Review. Journal of Microbial \& Biochemical Technology, 8(4). https://doi.org/10.4172/1948-5948.1000310

Hildebrandt, U., Regvar, M., \& Bothe, H. (2007). Arbuscular mycorrhiza and heavy metal tolerance. Phytochemistry, 68(1), 139-146. https://doi.org/10.1016/j.phytochem.2006.09.023 
Holt, H. G., Krieg, N. R., Sneath, P. H. A., Staley, J. T., \& Williams, S.T (2004). Bergey's Manual of Determinative Bacteriology. Baltimore: Williams and Wilkeus Co.

Shazia, I., Rukh Sadia, G., \& Talat, A. (2013). Bioremediation of Heavy Metals Using Isolates of Filamentous Fungus Aspergillus fumigatus Collected from Polluted Soil of Kasur, Pakistan. International Research Journal of Biological Sciences, 2(12), 66-73.

Jin, Y., Luan, Y., Ning, Y., \& Wang, L. (2018). Effects and mechanisms of microbial remediation of heavy metals in soil: A critical review. Applied Sciences (Switzerland), 8(8), 1336. https://doi.org/10.3390/app8081336

Kader, J., Sannas, P., Othman, O., Ismail, B. S., \& Salmijaji, S. (2007). Removal of Cr (VI) from aqueous solutions by group cells and non-growing cells population of environmental bacterial consortia. Bioresource Technology, 97(5), 740-747.

Kotaś, J., \& Stasicka, Z. (2000). Chromium occurrence in the environment and methods of its speciation. Environmental Pollution, 107(3), 263-283. https://doi.org/10.1016/S0269-7491(99)00168-2

Kumar, A., Bisht, B. S., Joshi, V. D., \& Dhewa, T. (2011). Review on bioremediation of polluted environment: A management Tool. International Journal of Environmental Science, 1, 6-8.

Li, J., Yu, H., \& Luan, Y. (2015). Meta-analysis of the copper, zinc, and cadmium absorption capacities of aquatic plants in heavy metal-pollutedwater. International Journal of Environmental Research and Public Health, 12(12), 14958-14973. https://doi.org/10.3390/ijerph121214959

Lyod, J. R. (2002). Bioremediation of metals; the application of microorganisms that make and break minerals. Microbiol. Today, 29, 67-69.

Marchenko, A. M., Pshinko, G. N., Demchenko, V. Y., \& Goncharuk, V. V. (2015). Leaching heavy metal from deposits of heavy metals with bacteria oxidizing elemental sulphur. Journal of Water Chemistry and Technology, 37(6), 311-316. https://doi.org/10.3103/S1063455X15060090

Mosa, K. A., Saadoun, I., Kumar, K., Helmy, M., \& Dhankher, O. P. (2016). Potential biotechnological strategies for the cleanup of heavy metals and metalloids. Frontiers in Plant Science, 7(MAR2016), 303. https://doi.org/10.3389/fpls.2016.00303

Mullen, M. D., Wolf, D. C., Ferris, F. G., Beveridge, T. J., Flemming, C. A., \& Bailey, G. W. (1989). Bacterial sorption of heavy metals. Applied and Environmental Microbiology, 55(12), 3143-3149. https://doi.org/10.1128/aem.55.12.3143-3149.1989

Neha, S., Tuhina, V., \& Rajeeva, G. (2013). Detoxification of CrVI by an indigenous facultative anaerobic Bacillus cereus isolated from tannery effluent. African Journal of Biotechnology, 12(10)

Park, J. H., Lee, S. J., Lee, M. E., \& Chung, J. W. (2016). Comparison of heavy metal immobilization in contaminated soils amended with peat moss and peat moss-derived biochar. Environmental Science: Processes and Impacts, 18(4), 514-520. https://doi.org/10.1039/c6em00098c

Park, J. H., Lee. S. J., Lee, M. E., \& Chung, J. W. (2016). Comparison of heavy metal immobilization in contaminated soils ammended with peat moss and peat-moss derived biochar. Environ. Sci. Process Impacts, $18,514-520$.

Puyen, Z. M., Villagrasa, E., Maldonado, J., Diestra, E., Esteve, I., \& Solé, A. (2012). Biosorption of lead and copper by heavy-metal tolerant Micrococcus luteus DE2008. Bioresource Technology, 126, 233-237. https://doi.org/10.1016/j.biortech.2012.09.036

Ramasamy, K., Kamaludeen, \& Banu, S. P. (2007). Bioremediation of metals: Microbial processes and techniques. In S. N. Singh \& R. D. Tripathi (Eds.), Environmental Bioremediation Technologies (pp. 173-187). Berlin, Heidelberg: Springer Berlin Heidelberg. https://doi.org/10.1007/978-3-540-34793-4_7

Rasmussen, L. D., Sørensen, S. J., Turner, R. R., \& Barkay, T. (2000). Application of a mer-lux biosensor for estimating bioavailable mercury in soil. Soil Biology and Biochemistry, 32(5), 639-646. https://doi.org/10.1016/S0038-0717(99)00190-X

Sannasi, P., Kader, J., Ismail, B. S., \& Salmijah, S. (2006). Sorption of $\mathrm{Cr}(\mathrm{VI}), \mathrm{Cu}(\mathrm{II})$ and $\mathrm{Pb}(\mathrm{II})$ by growing and non-growing cells of a bacterial consortium. Bioresource Technology, 97(5), 740-747. https://doi.org/10.1016/j.biortech.2005.04.007 
Seh-Bardan, B. J., Othman, R., Wahid, S. A., Husin, A., \& Sadegh-Zadeh, F. (2012). Bioleaching of heavy metals from mine tailings by aspergillus fumigatus. Bioremediation Journal, 16(2), $57-65$. https://doi.org/10.1080/10889868.2012.665958

Singh, A., \& Prasad, S. M. (2015). Remediation of heavy metal contaminated ecosystem: an overview on technology advancement. International Journal of Environmental Science and Technology, 12(1), 353-366. https://doi.org/10.1007/s13762-014-0542-y

Singh, S. N., \& Tripathi, R. D. (2007). Environmental bioremediation technologies. In S. N. Singh \& R. D. T. S.C. Tripathi (Eds.), Environmental Bioremediation Technologies. Berlin, Heidelberg: Springer Berlin Heidelberg. https://doi.org/10.1007/978-3-540-34793-4

Sivaruban, T., Barathy, S., Sivakumar, S., \& Mivan, S. (2014). Microbial removal of high concentration heavy metal in tannery. Research Journal of Pharmaceutical, Biological and Chemical Science, 5(4), 211-224.

Srivastava, S., Agrawal, S. B., \& Mondal, M. K. (2015). A review on progress of heavy metal removal using adsorbents of microbial and plant origin. Environmental Science and Pollution Research, 22(20), 1538615415. https://doi.org/10.1007/s11356-015-5278-9

Tang, Q., Shi, P., Zhang, Y., Liu, W., \& Chen, L. (2019). Strength and Deformation Properties of Fiber and Cement Reinforced Heavy Metal-Contaminated Synthetic Soils. Advances in Materials Science and Engineering, 2019, 1-9. https://doi.org/10.1155/2019/5746315

USEPA (1996). Method 3050B. Acid digestion of sediments, sludges and soils. Revision 2, Environmental Protection Agency, Washington, USA, 3-5.

Vidali, M. (2001). Bioremediation. An overview. Pure and Applied Chemistry, 73(7), $1163-1172$. https://doi.org/10.1351/pac200173071163

Wang, Y., Guo, J., \& Liu, R. (2001). Biosorption of heavy metals by bacteria isolated from activated sludge. Huanjing Kexue/Environmental Science, 22(6), 72-75. https://doi.org/10.1007/978-1-4612-0217-2_15

Wierzba, S. (2015). Biosorption of lead(II), zinc(II) and nickel(II) from industrial wastewater by Stenotrophomonas maltophilia and Bacillus subtilis. Polish Journal of Chemical Technology, 17(1), $79-87$. https://doi.org/10.1515/pjct-2015-0012

Yang, T., Chen, M. L., \& Wang, J. H. (2015). Genetic and chemical modification of cells for selective separation and analysis of heavy metals of biological or environmental significance. TrAC - Trends in Analytical Chemistry, 66, 90-102. https://doi.org/10.1016/j.trac.2014.11.016

Zhang, J. H., Peng, J. H., Zhang, T. C., Dai, C. J., \& Yaw, Y. S. (2019). Prediction of resilient inoculum of compacted soil in South China. International Journal of Geomechanics, 10(6), 248-249.

Zheng, I., \& Antonio, S. (2007). Prospective study of the world aluminium industry: World Bank> JRC Scientific Reports. Retrieved from ftp.jrc.es/EURdoc/JRC40221pdf.

Zouboulis, A. I., Loukidou, M. X., \& Matis, K. A. (2004). Biosorption of toxic metals from aqueous solutions by bacteria strains isolated from metal-polluted soils. Process Biochemistry, 39(8), 909-916. https://doi.org/10.1016/S0032-9592(03)00200-0

\section{Appendix A}

Table 3b: Summary of t-test Analysis of Significant Mean Difference Between the $1^{\text {st }}$ Week and $12^{\text {th }}$ Weeks with the Controls and Treatments of Cadmium Concentration.

\begin{tabular}{lllllllll}
\hline Week & Mean & Std & Variance & Treatment & df & t cal. & t Crit. & P<0.05 \\
\hline 1 st & 1.86 & 1.54 & 2.36 & 24 & \multirow{2}{*}{23.46} & \multirow{2}{*}{1.71} & \\
\hline 12 th & 1.71 & 1.45 & 2.11 & 24 & & & \\
\hline
\end{tabular}

In Table 3b, since the t-cal. (3.46) higher than the t-critical (1.71) with difference (23) at $\mathrm{p}<0.05$ level of significance, there exist significance difference in the mean cadmium concentration between the $1^{\text {st }}$ and $12^{\text {th }}$ weeks among the controls and their treatments. 


\section{Appendix B}

Table 4b: Summary t-test Analysis to Significant Mean Difference Between the $1^{\text {st }}$ Week and $12^{\text {th }}$ Weeks with the Controls and Their Treatments of Chromium Concentration.

\begin{tabular}{lllllllll}
\hline Week & Mean & Std & Variance & Treatment & df & t cal. & t Crit. & P $<\mathbf{0 . 0 5}$ \\
\hline 1st & 1.24 & 0.98 & 0.96 & 24 & \multirow{2}{*}{23} & \multirow{2}{*}{5.81} & \multirow{2}{*}{1.71} & \multirow{2}{*}{0.0001} \\
\hline 12 th & 1.02 & 0.89 & 0.79 & 24 & & & & \\
\hline
\end{tabular}

In Table 4b, since the t-cal. (5.81) greater than the t-critical (1.71) with difference (23) at $\mathrm{p}<0.05$ level of significance, there exist significance difference in the mean chromium concentration between the $1^{\text {st }}$ and $12^{\text {th }}$ weeks among the controls and their treatments.

\section{Appendix C}

Table 5b: Summary t-test Analysis of Significant Mean Difference Between the $1^{\text {st }}$ Week and $12^{\text {th }}$ Weeks with the Controls and Treatments of Nickel Concentration

\begin{tabular}{lllllllll}
\hline Week & Mean & Std & Variance & Treatment & df & t cal. & t Crit. & P<0.05 \\
\hline 1st & 20.12 & 16.63 & 276.44 & 24 & \multirow{2}{*}{23} & \multirow{2}{*}{4.69} & \multirow{2}{*}{1.71} & \multirow{2}{*}{0.0001} \\
\hline 12 th & 17.66 & 15.32 & 234.60 & 24 & & &
\end{tabular}

In Table 5b, since the t-cal. (4.69) higher than the t-critical (1.71) with difference (23) at $\mathrm{p}<0.05$ level of significance, there was significance difference in the mean nickel concentration between $1^{\text {st }}$ and $12^{\text {th }}$ weeks among the controls and their treatments.

\section{Appendix D}

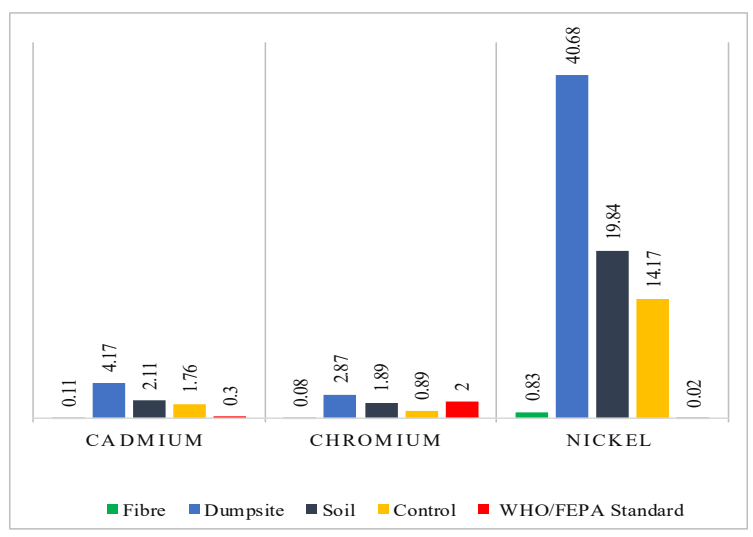

Fig.1: Bar chart showing the concentrations of $\mathrm{Cd}, \mathrm{Cr}$ and $\mathrm{Ni}$ in the various samples as compared to WHO/FEPA standard.

\section{Appendix E}

\section{One-way ANOVA: Cr, Cd, Ni}

\section{Method}

$\begin{array}{ll}\text { Null hypothesis } & \text { All means are equal } \\ \text { Alternative hypothesis } & \text { Not all means are equal } \\ \text { Significance level } & \alpha=0.05\end{array}$

Equal variances were not assumed for the analysis.

Factor Information

\begin{tabular}{lll} 
Factor & Levels & Values \\
\hline Factor & 3 & $\mathrm{Cr}, \mathrm{Cd}, \mathrm{Ni}$
\end{tabular}




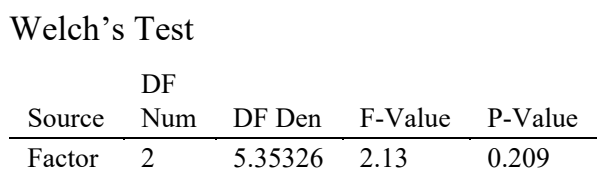

\section{Model Summary}

\begin{tabular}{lll} 
R-sq & R-sq(adj) & R-sq(pred) \\
\hline $14.35 \%$ & $0.07 \%$ & $0.00 \%$
\end{tabular}

\section{Means}

\begin{tabular}{lllll} 
Factor & $\mathrm{N}$ & Mean & StDev & $95 \% \mathrm{CI}$ \\
\hline $\mathrm{Cr}$ & 5 & 10.12 & 17.12 & $(-11.14,31.38)$ \\
$\mathrm{Cd}$ & 5 & 0.498 & 0.481 & $(-0.100,1.096)$ \\
$\mathrm{Ni}$ & 5 & 7.61 & 8.85 & $(-3.38,18.59)$
\end{tabular}

\section{Copyrights}

Copyright for this article is retained by the author(s), with first publication rights granted to the journal.

This is an open-access article distributed under the terms and conditions of the Creative Commons Attribution license (http://creativecommons.org/licenses/by/4.0/). 